Article

\title{
Influence of Biochar Derived Nitrogen on Cadmium Removal by Ryegrass in a Contaminated Soil
}

\author{
João Antonangelo *(1) and Hailin Zhang (1) \\ Plant and Soil Sciences Department, Oklahoma State University, Stillwater, OK 74078, USA; \\ hailin.zhang@okstate.edu \\ * Correspondence: joao.antonangelo@okstate.edu; Tel.: +1-405-780-3950
}

Citation: Antonangelo, J.; Zhang, $\mathrm{H}$. Influence of Biochar Derived Nitrogen on Cadmium Removal by Ryegrass in a Contaminated Soil. Environments 2021, 8, 11. https:// doi.org/10.3390/environments8020011

Academic Editor:

Dionisios Gasparatos

Received: 7 January 2021

Accepted: 2 February 2021

Published: 8 February 2021

Publisher's Note: MDPI stays neutral with regard to jurisdictional claims in published maps and institutional affiliations.

Copyright: (c) 2021 by the authors. Licensee MDPI, Basel, Switzerland. This article is an open access article distributed under the terms and conditions of the Creative Commons Attribution (CC BY) license (https:// creativecommons.org/licenses/by/ $4.0 /)$.

\begin{abstract}
Little is known about the effect of nitrogen $(\mathrm{N})$ application via biochar on the removal of trace elements by crops, and the effects with chemical fertilizers are inconsistent. We determined, from a previous study, the influence of increased $\mathrm{N}$ addition via biochars produced from switchgrass (SGB) and poultry litter (PLB) on cadmium (Cd) removal by ryegrass. The biochar rates of $0,0.5,1,2$, and $4 \% w / w$ were applied to a Cd-contaminated soil before seeding in a potting experiment with a complete randomized block design (CRBD). Ryegrass yield and $\mathrm{N}$ and $\mathrm{Cd}$ removed by harvest were strongly related $(p<0.05)$. The ryegrass yields increased up to $1 \%$ of PLB, and Cd removal was also the highest at $1 \%$ of PLB. The biomass of ryegrass roots increased with Cd accumulation $(p<0.05)$. Overall, the $\mathrm{Cd}$ transfer factor $(\mathrm{TF})$ from ryegrass roots to shoots increased when up to $206 \pm 38 \mathrm{~kg} \mathrm{~N} \mathrm{ha}^{-1}$ was removed in ryegrass shoots $(p<0.0001)$. The application of PLB up to $1 \%$ might be a viable option since it is a practical rate for handling operations requiring less volume of material than SGB. Additionally, the Cd concentration in the aboveground forage remained acceptable for grazing cattle. Future studies are encouraged to evaluate different sources of $\mathrm{N}$ fertilizers affecting Cd uptake on cash crops.
\end{abstract}

Keywords: cadmium; biochar application rates; metal accumulation; nitrogen; ryegrass

\section{Introduction}

Human activities have gradually transferred many toxic metals from the earth's crust to the environment, resulting in the spread and contamination of toxic metals in the ecosystem [1-4]. The metals originate from many sources including mining activities, industrial waste disposals, paints, and gasoline additives that lead to physical and chemical processes such as leaching and oxidation thus causing the accumulation of metals in the soil. Toxic metal pollution has become a serious problem worldwide in the last decade. Cadmium (Cd) is considered the most toxic element among toxic metals for living organisms and has been detected in some agricultural lands [1]. Cadmium accumulates in plants and animals and threatens their health when entering through the food chain [5,6]. Thus, it is important but challenging to remediate Cd-contaminated soils worldwide.

The Tar Creek area is designated as a superfund site located in the tri-state regions of Oklahoma, Kansas, and Missouri by US Environmental Protection Agency (EPA), and is one of the most polluted sites in the world [7]. A Superfund site is an abandoned hazardous waste site in the United States subject to the Comprehensive Environmental Response, Compensation and Liability Act (CERCLA), which allows federal funding to be spent on investigating and remediating the environmental contamination at the designated site. The Tar Creek area was mined for approximately 70 years starting from the beginning of the 1900s. Large quantities of coarse material contaminated with Cd were left on the ground surface in piles due to the mining and milling operations. Such a coarse material is gravellike waste well known as "chat pile." The large size and the considerable amount of chat piles resulted in $\mathrm{Cd}$ contamination in the surrounding areas due to wind blowing and the 
chat materials used as gravel. Reclamations of contaminated lands have been attempted by the US Government and the Quapaw Tribe. Although the status of Cd contamination in the Tar Creek has been addressed in numerous studies [8-10], with some of them elucidating the use of biochars for $\mathrm{Cd}$ remediation and phytoavailability reduction [11], there is still a lack of research evaluating the effect of nitrogen $(\mathrm{N})$ application via biochars on the accumulation of $\mathrm{Cd}$ by crops.

Nitrogen is the most important essential nutrient for plants, and $\mathrm{N}$ application is the biggest contributor to biomass production [12]. Although some studies suggested that $\mathrm{Cd}$ concentration in plants decreased as their biomass increased by $\mathrm{N}$ application [13,14], other works concluded that $\mathrm{N}$ fertilizer not only improved plants' biomass but also increased their Cd concentration [12,15-17]. In an experiment conducted by Symanowicz et al. [18], $\mathrm{N}$ fertilization significantly contributed to increase $\mathrm{Cd}$ accumulation in the aboveground portion (shoots) of eastern galega. Thus, the effect of $\mathrm{N}$ application on $\mathrm{Cd}$ accumulation remains controversial [12]. In general, $\mathrm{N}$ fertilization often decreases soil $\mathrm{pH}$, which increases the solubility and mobility of $\mathrm{Cd}$ in the soil [19,20]. Ji et al. [12] also highlighted a more direct effect of $\mathrm{N}$ fertilization in $\mathrm{Cd}$ uptake by suggesting a mechanism in which the active uptake and influx rate of $\mathrm{Cd}^{2+}$ into the roots of Italian ryegrass (Lolium multifolorum Lam.) were enhanced by the greater affinity of the membrane transporter to $\mathrm{Cd}^{2+}$ as a consequence of the urea application.

Although the studies mentioned above have evaluated the effect of $\mathrm{N}$ on $\mathrm{Cd}$ bioavailability and plant uptake, all of them were performed through the addition of chemical fertilizers. Therefore, the evaluation of $\mathrm{N}$ addition using biochar aiming the same goal makes our research unique since there might be a compound effect of biochar properties, such as alkalinity and surface functional groups, also affecting Cd uptake, not just the $\mathrm{N}$ addition itself.

Perennial ryegrasses (Lolium perenne) are widely used in grazed pastures due to its potential to reduce nitrate $\left(\mathrm{NO}_{3}{ }^{-}\right)$leaching [21], which makes such grass a potential scavenger of soil N. Ryegrass is also known for its efficient phytoaccumulation of toxic metals such as $\mathrm{Cd}$ [11]. These characteristics make ryegrass a promising tool to study the $\mathrm{N}$ and $\mathrm{Cd}$ accumulation relationship in plant tissues. It is a gramineous grass with fast growth, high yield potential, strong resistance to toxic metals, and able to normally grow in tailing areas where toxic metal pollution is severe and the environment is harsh [12]. Moreover, Mongkhonsin et al. [22] pointed out that ryegrass shoots had the highest Cd enrichment of up to fourfold of what is commonly found in other plant species that are hyperaccumulators (Solanum nigrum and Indian mustard); and Italian ryegrass had the strongest tolerance and accumulation capacity of $\mathrm{Cd}$ among eight $\mathrm{C} 3$ herbage grass species. Therefore, the perennial ryegrass with high biomass yields is also an appropriate species to use for the remediation of Cd-contaminated soils [23].

Our objective was to determine the influence of increased $\mathrm{N}$ addition via biochar derived from two feedstocks on $\mathrm{Cd}$ removal by ryegrass. This study is derived from the work of Antonangelo and Zhang [11] and data were reanalyzed to evaluate the $\mathrm{N}$ and $\mathrm{Cd}$ removal instead of their simple uptake. Since current literature is undoubtedly deficient in such information, we believe that our research has the potential to expand from small-scale to field-scale studies. This will serve as a multi-purpose biochar application to increase forage biomass and $\mathrm{Cd}$ uptake for phytoremediation purposes, at the same time immobilizing a certain amount of bioavailable $\mathrm{Cd}$ in the soil, as observed with the previous study of Antonangelo and Zhang [11], thus avoiding its leaching to the groundwater.

This would be a pioneering work for other studies focusing on $\mathrm{N}$ rates from biochars and/or the combination of biochar $+\mathrm{N}$ fertilizers to increase toxic metal phytoaccumulation while immobilizing the metal in the soil-plant system. This multi-purpose aspect contributes to the sustainable use of resources, since only immobilization is not enough if there is a need for disposal, land application, or landfill. Hence, if animal grazing is needed in such contaminated areas, the risk of intoxication could be still avoided depending on 
the metal accumulation in shoots. A sustainable attitude (multi-purpose) like this might be useful for contaminated lands, such as the Tar Creek superfund site.

\section{Materials and Methods}

\subsection{Biochar Production and Characteristics}

The biochars used were converted from switchgrass (SG; Panicum virgatum) and poultry litter (PL) via slow pyrolysis at $700{ }^{\circ} \mathrm{C}$. The feedstocks obtainment and the detailed description of their conversion into biochar products can be found in Antonangelo and Zhang [11]. Switchgrass- and poultry litter-derived biochars are referred to as SGB and PLB, respectively. The biochars coarse materials were ground with a mortar and pastel gently before sieved through $1 \mathrm{~mm}$ for further physicochemical analyses [24] and through $0.25 \mathrm{~mm}$ for the potting experiment. A full characterization of SGB and PLB including all physicochemical properties such as moisture, ash content, particle-size distribution, elemental composition, surface functional groups, chemical attributes, specific surface area, cation exchange capacity (CEC), and morphology can be found in [24]. For this study, it is useful to emphasize the ash, total carbon (TC), total nitrogen (TN), phosphorus $(\mathrm{P})$, potassium $(\mathrm{K})$, calcium $(\mathrm{Ca})$, magnesium $(\mathrm{Mg})$, and sulfur (S) contents, as presented in Table 1.

Table 1. Physicochemical properties of biochar derived from switchgrass (SGB) and poultry litter.

\begin{tabular}{cccc}
\hline Property & Unit & SGB & PLB \\
\hline Ash & $\%$ & 4.4 & 45.9 \\
TC & $\mathrm{g} \mathrm{kg}^{-1}$ & $314 \pm 13$ & $278 \pm 14$ \\
TN & $\mathrm{g} \mathrm{kg}^{-1}$ & $7 \pm 0$ & $16 \pm 1$ \\
P & $\mathrm{g} \mathrm{kg}^{-1}$ & $2 \pm 0.2$ & $40 \pm 0.8$ \\
K & $\mathrm{g} \mathrm{kg}^{-1}$ & $4 \pm 0.4$ & $80 \pm 0.6$ \\
$\mathrm{Ca}$ & $\mathrm{g} \mathrm{kg}^{-1}$ & $8 \pm 1$ & $50 \pm 2$ \\
$\mathrm{Mg}$ & $\mathrm{g} \mathrm{kg}^{-1}$ & $3 \pm 0$ & $20 \pm 0.1$ \\
$\mathrm{~S}$ & $\mathrm{~g} \mathrm{~kg}^{-1}$ & $0.4 \pm 0.1$ & $10 \pm 0.6$ \\
\hline
\end{tabular}

Numbers followed by " \pm " are the standard deviations of triplicates $(\mathrm{n}=3)$.

\subsection{Soil Sampling and Analysis}

Cadmium contaminated soil samples were collected with a shovel $(0$ to $15 \mathrm{~cm})$ from a residential yard near chat piles located in Picher, Ottawa County, Oklahoma. Soil sample preparation for analyses and for the potting experiment was described in Antonangelo and Zhang [11]. Before and after the pot experiment, soil samples were analyzed for DTPA-extractable $\mathrm{Cd}$. Before the potting experiment, the total $\mathrm{Cd}$ content was determined by an inductively coupled plasma-atomic emission spectroscopy, ICP-AES (SPECTRO Analytical Instruments $\mathrm{GmbH}$, Boschstr. 10, 47533 Kleve, Germany) after digestion by concentrated $\mathrm{HNO}_{3}$ and $\mathrm{H}_{2} \mathrm{O}_{2}$ using EPA method 3050B [25]. The TN, and total and DTPA-extractable $\mathrm{Cd}$ before the potting experiment were respectively $1.7 \pm 0.1 \mathrm{~g} \mathrm{~kg}^{-1}$, $9 \pm 0.6 \mathrm{mg} \mathrm{kg}^{-1}$, and $1.84 \pm 0.03 \mathrm{mg} \mathrm{kg}^{-1}$. The total $\mathrm{Cd}$ content was about tenfold the maximum found in normal Oklahoma soils [26]. The DTPA-extractable Cd has been considered the most efficient method to predict the $\mathrm{Cd}$ phytoavailability to grasses, such as rice (Oryza sativa) [27] and perennial ryegrass [11]. Still, the threshold of DTPA-extractable $\mathrm{Cd}$ found by Wu et al. [27] was 0.03 to $0.16 \mathrm{mg} \mathrm{kg}^{-1}$ depending on the soil organic matter (SOM) content, which is more than 10 times lower than the content found in the Tar Creek soil of this study.

\subsection{Potting Experiment}

Plastic pots were filled with $1.2 \mathrm{~kg}$ of $2 \mathrm{~mm}$ sieved soils and amended with 0.0 (control), $0.5,1.0,2.0$, and $4.0 \%(w / w)$ of $0.25 \mathrm{~mm}$ sieved SGB and PLB. The biochar-amended soils were incubated for approximately 30 days at $75 \%$ of field capacity before ryegrass sowing in each pot at $30 \mathrm{~kg} \mathrm{ha}^{-1}$. Ryegrass was grown for $\sim 75$ days in the biochar amended soils in an environmentally controlled growth chamber. The pots were arranged in a complete 
randomized block design $($ CRBD) with 3 replicates $(n=3)$ and rotated weekly to eliminate spatial variability in the chamber. All procedures and analyses conducted during the potting experiment are detailed in Antonangelo and Zhang [11].

\subsection{Nitrogen and Cadmium Analysis in Ryegrass Shoots and Roots}

After harvesting, ryegrass shoots and roots were separated, washed with D.I. water, and oven-dried to constant weight at $105^{\circ} \mathrm{C}$, and their weight was recorded. Dried plant materials were ground using a mechanical grinder and further analyses were followed. Ground plant materials were analyzed for $\mathrm{Cd}$ using nitric acid digestion and $\mathrm{TN}$ using dry combustion and determination via LECO, as previously described for soil. For Cd in plant tissues, $0.5 \mathrm{~g}$ of ground plant materials were predigested for $1 \mathrm{~h}$ with $10 \mathrm{~mL}$ of trace metal grade $\mathrm{HNO}_{3}$ in the HotBlock ${ }^{\mathrm{TM}}$ Environmental Express block digester (Environmental Express, 2345A Charleston Regional Parkway, Charleston, SC, USA), and the digestion products were then heated to $115^{\circ} \mathrm{C}$ for $2 \mathrm{~h}$ and diluted with D.I. water to $50 \mathrm{~mL}$ [28]. Finally, the digested samples were filtered and analyzed for Cd by an ICP-AES.

The $\mathrm{N}$ and $\mathrm{Cd}$ concentration determined in plant tissues (uptake) was multiplied by their respective biomass to eliminate any dilution effect caused by over yield and the $\mathrm{N}$ and $\mathrm{Cd}$ in ryegrass shoots and/or roots were then treated as "removed" (shoots, when harvested) and/or "accumulated": N/Cd removed/accumulated $=(N / C d$ concentration $\times$ Yield $)$.

The $\mathrm{Cd}$ transfer factor (TF) was calculated by considering the $\mathrm{Cd}$ removal and accumulation following: $T F=(\mathrm{Cd}$ removed in shoots $\div \mathrm{Cd}$ accumulated in roots $)$.

\subsection{Statistical Analysis}

Ryegrass $\mathrm{N}$ and $\mathrm{Cd}$ accumulation in ryegrass tissues and $\mathrm{Cd}$ TF from ryegrass shoots to roots, as described above, were subjected to a two-way ANOVA following the CRBD and the average of the treatments (biochar rates and biochar from different feedstocks) compared by the Tukey test at $5 \%(p \leq 0.05)$. Analysis of covariance (ANCOVA) was performed for the linear regressions between ryegrass yield and $\mathrm{N}$ accumulation and between $\mathrm{N}$ and $\mathrm{Cd}$ accumulations to plot the linear models with both biochars combined or for each biochar separately, depending on the results. Data analysis was performed using SAS version 9.4.

The maximum $\mathrm{N}$ removal from which the highest $\mathrm{Cd}$ TF is reached was determined by fitting the segmented linear-plateau response model using the NLIN (nonlinear) procedure of SAS version 9.4. Pearson's simple correlation for specific variables has also been carried out. Regression analyses and Pearson correlation were performed with the whole dataset of measurements (all replicate data) at $\alpha=0.05$ for both model fitting and equation coefficients. Graphs were plotted with the assistance of Excel.

\section{Results}

\subsection{Ryegrass Production, and Cadmium $\times$ Nitrogen Accumulation Relationship}

Ryegrass $\mathrm{N}$ and Cd accumulation are shown in Table 2. A two-way ANOVA was conducted to test the differences among biochar rates and between the two different feedstockderived biochars for a given rate. This was because the interaction rate $(R) \times$ biochar $(B)$ was significant $(p<0.05)$ in all cases: shoots, roots, and shoots + roots (Table 2$)$. As highlighted in the previous work of Antonangelo and Zhang [11], the ryegrass shoots, roots, and whole plant (shoots + roots) yielded better when treated with PLB presenting, on average, an increase of 64, 51, and 59\% respectively when compared to those treated with SGB (Table 2). Similarly, N and Cd accumulation had an overall increase of 88, 60, and 84\%, and 71, 30, and $40 \%$ respectively, when PLB was applied (Table 2 ). At 0.5 and $1 \%$ of PLB application, the ryegrass shoots presented the highest $\mathrm{N}$ and $\mathrm{Cd}$ accumulation (Table 2), accompanied by their highest yields. This is the first indication that $\mathrm{Cd}$ accumulation increases as the ryegrass yield increase with $\mathrm{N}$ accumulation. The approximately $35 \mathrm{~g} \mathrm{Cd}$ removed ha ${ }^{-1}$ in ryegrass shoots after PLB application at 0.5 and $1 \%$ (Table 2 ) is equivalent to a concentration of $3.4 \pm 0.1 \mathrm{mg} \mathrm{kg}^{-1}$ (dry matter, DM) in our study, which is still far below the maximum 
tolerable concentration of $10 \mathrm{mg} \mathrm{kg}^{-1}$ for animal grazing [29]. The Cd accumulation in ryegrass plant parts decreased with biochar application rates regardless the feedstock from which the biochar was produced (Table 2). However, it must be pointed out that such reduction is not only a consequence of the reduced $\mathrm{N}$ removal and ryegrass yields at $4 \%$ of biochar amendment but also due to a direct effect of the biochar properties with the potential to immobilize $\mathrm{Cd}$ in the soil, amongst them surface functional groups, alkalinity, organic carbon (OC), and CEC [24].

Table 2. Nitrogen $(\mathrm{N})$ and cadmium $(\mathrm{Cd})$ accumulation in ryegrass shoots, roots, and shoots + roots as a function of biochar (B) application rates (R).

\begin{tabular}{|c|c|c|c|c|c|c|c|c|c|c|c|c|}
\hline \multirow{4}{*}{$\begin{array}{c}\text { Rate (\%) } \\
0\end{array}$} & \multicolumn{12}{|c|}{ Shoots } \\
\hline & \multicolumn{6}{|c|}{$\mathrm{N}\left(\mathrm{kg} \mathrm{ha}^{-1}\right)$} & \multicolumn{6}{|c|}{$\mathrm{Cd}\left(\mathrm{g} \mathrm{ha}^{-1}\right)$} \\
\hline & \multicolumn{2}{|c|}{ SGB } & \multicolumn{2}{|c|}{ PLB } & \multicolumn{2}{|c|}{ Mean } & \multicolumn{2}{|c|}{ SGB } & \multicolumn{2}{|c|}{ PLB } & \multicolumn{2}{|c|}{ Mean } \\
\hline & 221 & $\mathrm{aA}$ & 221 & $\mathrm{cA}$ & 221 & $\mathrm{a}$ & 30 & $\mathrm{aA}$ & 30 & $\mathrm{aA}$ & 30 & $\mathrm{a}$ \\
\hline 0.5 & 113 & $\mathrm{bB}$ & 287 & $\mathrm{aA}$ & 200 & $\mathrm{~b}$ & 15.2 & $\mathrm{bB}$ & 35.5 & $\mathrm{aA}$ & 25.4 & a \\
\hline 1 & 99 & $\mathrm{bB}$ & 268 & $\mathrm{bA}$ & 183 & $b$ & 14.3 & $\mathrm{bB}$ & 34.7 & $\mathrm{aA}$ & 24.5 & a \\
\hline 2 & 72 & $\mathrm{cB}$ & 180 & $\mathrm{dA}$ & 126 & $\mathrm{c}$ & 10.6 & $\mathrm{bB}$ & 21.6 & $\mathrm{bA}$ & 16.1 & $\mathrm{~b}$ \\
\hline 4 & 19 & $\mathrm{~dB}$ & 28 & $\mathrm{eA}$ & 24 & $\mathrm{~d}$ & 2.3 & $\mathrm{cA}$ & 2.4 & $\mathrm{cA}$ & 2.3 & c \\
\hline Mean & 105 & B & 197 & A & & & 14.5 & B & 24.8 & A & & \\
\hline$R$ & \multicolumn{6}{|c|}{$p<0.05$} & \multicolumn{6}{|c|}{$p<0.05$} \\
\hline$B$ & \multicolumn{6}{|c|}{$p<0.05$} & \multicolumn{6}{|c|}{$p<0.05$} \\
\hline$R \times B$ & \multicolumn{6}{|c|}{$p<0.05$} & \multicolumn{6}{|c|}{$p<0.05$} \\
\hline \multirow[t]{3}{*}{ Rate (\%) } & \multicolumn{12}{|c|}{ Roots } \\
\hline & \multicolumn{6}{|c|}{$\mathrm{N}\left(\mathrm{kg} \mathrm{ha}^{-1}\right)$} & \multicolumn{6}{|c|}{$\mathrm{Cd}\left(\mathrm{g} \mathrm{ha}^{-1}\right)$} \\
\hline & \multicolumn{2}{|c|}{ SGB } & \multicolumn{2}{|c|}{ PLB } & \multicolumn{2}{|c|}{ Mean } & \multicolumn{2}{|c|}{ SGB } & \multicolumn{2}{|c|}{ PLB } & & \\
\hline 0 & 4.95 & $\mathrm{aA}$ & 4.95 & $\mathrm{cA}$ & 4.95 & $b$ & 45.9 & $\mathrm{aA}$ & 45.9 & $\mathrm{cA}$ & 45.9 & $a b$ \\
\hline 0.5 & 3.84 & $\mathrm{bB}$ & 8.29 & $\mathrm{aA}$ & 6.06 & $\mathrm{a}$ & 60.5 & $\mathrm{aB}$ & 90.6 & $\mathrm{abA}$ & 75.5 & $\mathrm{a}$ \\
\hline 1 & 3.42 & $\mathrm{bcB}$ & 7.11 & $\mathrm{bA}$ & 5.27 & $a b$ & 61.7 & $\mathrm{aB}$ & 109.7 & $\mathrm{aA}$ & 85.7 & a \\
\hline 2 & 2.52 & $\mathrm{cdB}$ & 4.91 & $\mathrm{cA}$ & 3.71 & $c$ & 40.9 & $\mathrm{aA}$ & 52.7 & bcA & 46.8 & $a b$ \\
\hline 4 & 2.04 & $\mathrm{dA}$ & 1.49 & $\mathrm{dA}$ & 1.76 & $\mathrm{~d}$ & 36.7 & $\mathrm{aA}$ & 15.3 & $\mathrm{cA}$ & 26 & $\mathrm{~b}$ \\
\hline Mean & 3.35 & B & 5.35 & A & & & 49.1 & B & 62.8 & $\mathrm{~A}$ & & \\
\hline$R$ & & & & & & & & & & & & \\
\hline$B$ & & & & & & & & & & & & \\
\hline$R \times B$ & & & & & & & & & & & & \\
\hline Rate (\%) & & & & & & Shoo & Roots & & & & & \\
\hline & & & $\mathrm{N}(1$ & $-1)$ & & & & & $\mathrm{Cd}($ & $-1)$ & & \\
\hline & & & & & & & & & & & & \\
\hline 0 & 334 & $\mathrm{aA}$ & 334 & $\mathrm{bA}$ & 334 & $\mathrm{a}$ & 193.6 & $\mathrm{aA}$ & 193.6 & $\mathrm{bA}$ & 193.6 & bc \\
\hline 0.5 & 180 & $\mathrm{bB}$ & 443 & $\mathrm{aA}$ & 312 & $a b$ & 205.8 & $\mathrm{aB}$ & 343.7 & $\mathrm{aA}$ & 274.8 & $a b$ \\
\hline 1 & 157 & $\mathrm{bB}$ & 419 & $\mathrm{aA}$ & 288 & $\mathrm{~b}$ & 208.4 & $\mathrm{aB}$ & 383.5 & $\mathrm{aA}$ & 296 & $\mathrm{a}$ \\
\hline 2 & 114 & $\mathrm{cB}$ & 281 & $\mathrm{cA}$ & 198 & $\mathrm{c}$ & 142.1 & $\mathrm{abB}$ & 195.2 & $\mathrm{bA}$ & 168.6 & c \\
\hline 4 & 43 & $\mathrm{dA}$ & 54 & $\mathrm{dA}$ & 48 & $\mathrm{~d}$ & 75.6 & $\mathrm{bA}$ & 39.4 & $\mathrm{cA}$ & 57.5 & d \\
\hline Mean & 166 & $\mathrm{~B}$ & 306 & $\mathrm{~A}$ & & & 165.1 & B & 231.1 & $\mathrm{~A}$ & & \\
\hline$R$ & & & & & & & & & & & & \\
\hline$B$ & & & & & & & & & & & & \\
\hline$R \times B$ & & & & & & & & & & & & \\
\hline
\end{tabular}

SGB: switchgrass-derived biochar. PLB: poultry litter-derived biochar. Different lowercase letters in columns (within biochar rates) and uppercase letters in rows (same biochar rate) are significantly different at $p<0.05$ (Tukey).

Table 3 shows the ANCOVA of linear regressions between ryegrass yield and $\mathrm{N}$ accumulation and between $\mathrm{N}$ and $\mathrm{Cd}$ accumulations plotted in Figure 1. Conversely to ANOVA, the interactions of biochar $\times$ yield and biochar $\times$ nitrogen from ANCOVA were not significant in ryegrass shoots and roots $(p>0.05)$, except for the whole plant when evaluating the biochar $\times$ nitrogen interaction in the relationship between $\mathrm{N}$ and $\mathrm{Cd}$ 
accumulations $(p<0.05)$ (Table 3$)$. Therefore, most relationships were plotted with both biochars combined (Figure 1a-e).

Table 3. Analyses of covariance (ANCOVA) from linear regression models between nitrogen (N) and ryegrass yield and between cadmium $(\mathrm{Cd})$ and $\mathrm{N}$ accumulations.

\begin{tabular}{cccc}
\hline Factor & Shoots & Roots & Shoots + Roots \\
\hline Biochar & $p=0.9503$ & N accumulated (y-axis) & \\
Yield & $p<0.0001$ & $p=0.4765$ & $p=0.5697$ \\
Biochar $\times$ Yield & $p=0.1767$ & $p=0.0005$ & $p<0.0001$ \\
& $p=0.2452$ & $p=0.0731$ \\
Biochar & $p=0.1051$ & Cd accumulated (y-axis) & \\
Nitrogen & $p<0.0001$ & $p=0.4597$ & $p=0.4012$ \\
Biochar $\times$ Nitrogen & $p=0.8557$ & $p=0.0003$ & $p=0.0001$ \\
When $p \leq 0.05$ the effect test is significant for the designated factor. When the interaction biochar $\times$ yield or nitrogen \\
is $p \leq 0.05$, results must be presented as two regression lines, one for each biochar.
\end{tabular}

Figure 1 clearly shows that $\mathrm{N}$ accumulation increases as a function of biochar application rates regardless of its feedstock, and such an accumulation contributes to ryegrass yield increases in shoots and roots. Concomitantly, the $\mathrm{Cd}$ accumulation of those plant parts follows their yields increment as well (Figure 1). This agrees with the findings of [12,15-18] who observed greater yields with increased $\mathrm{N}$ rates and consequently greater $\mathrm{Cd}$ uptake in the studied plants. In fact, $\mathrm{N}$ is the most limiting nutrient as far as yield increase is concerned and, in the case of our study, the same evaluations carried out for $\mathrm{P}$ and $\mathrm{K}$ showed a positive correlation with ryegrass yields but no relationship was found between $\mathrm{P}$ and $\mathrm{K}$ with $\mathrm{Cd}$ accumulation in any plant part (data not shown). Opposite to the increase of $\mathrm{Cd}$ accumulation in ryegrass plant parts, the $\mathrm{Cd}$ concentration in ryegrass shoots and roots, when their yields are not accounted for, decreased considerably with biochar application due to immobilization effect of phytoavailable $\mathrm{Cd}$ as a direct consequence of biochar properties, as observed in the previous study [11].

Curiously, the relationship between the yield of ryegrass roots and $\mathrm{Cd}$ accumulation was highly positive regardless of the biochar (Figure 2). There was an increment of $23 \mathrm{mg}$ $\mathrm{Cd}$ accumulated ha ${ }^{-1}$ for every $\mathrm{kg}$ of ryegrass roots increase (Figure 2). The maximum accumulation in the range of 80 to $160 \mathrm{~g} \mathrm{Cd} \mathrm{ha}^{-1}$ is related to the PLB at 0.5 and $1 \%$ application rates (Table 2, and Figures 1 and 2). Feng et al. [30] also reported an increase in root yields $(\mathrm{DM})$ of two ryegrass varieties when the levels of phytoavailable Cd were higher. This might be attributed to the fact that root density is higher in the presence of this toxic metal. However, Feng et al. [30] also observed that ryegrass roots although presenting higher enrichment ability for $\mathrm{Cd}$, its transportability to shoots was poor. Not surprisingly, the accumulation of $\mathrm{Cd}$ in ryegrass roots was much higher than in shoots in the case of our study (Table 2 and Figure 1e). This larger accumulation of $\mathrm{Cd}$ in the roots is also a cause of the lower $\mathrm{Cd}$ transference to the shoots [31,32], as will be discussed further. 

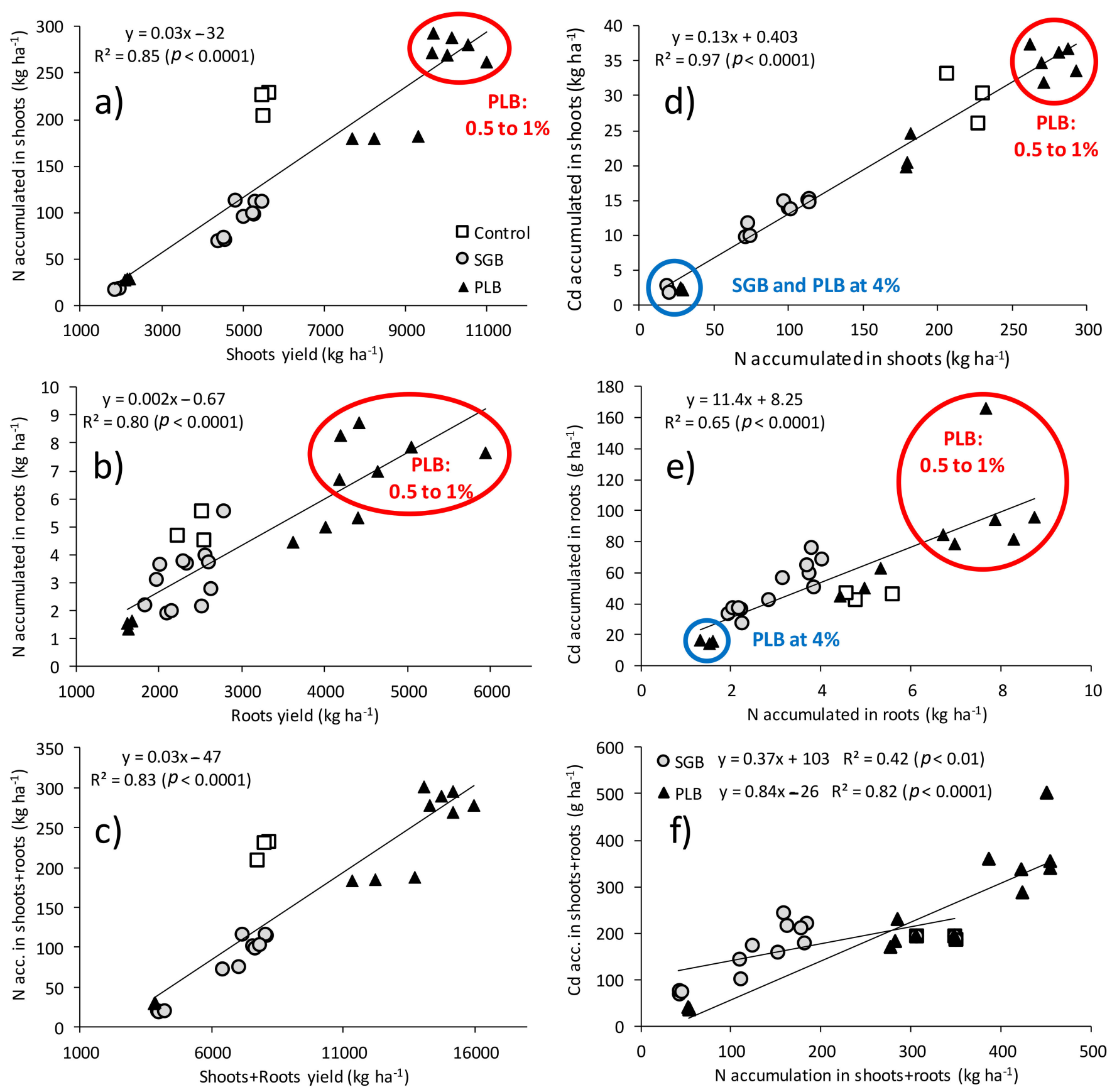

Figure 1. Relationships between ryegrass yield and $\mathrm{N}$ accumulation $(\mathbf{a}-\mathbf{c})$ and between nitrogen $(\mathrm{N})$ and cadmium $(\mathrm{Cd})$ accumulations in ryegrass shoots and roots $(\mathbf{d}-\mathbf{f})$ as functions of biochar application rates; acc.- -accumulated. 


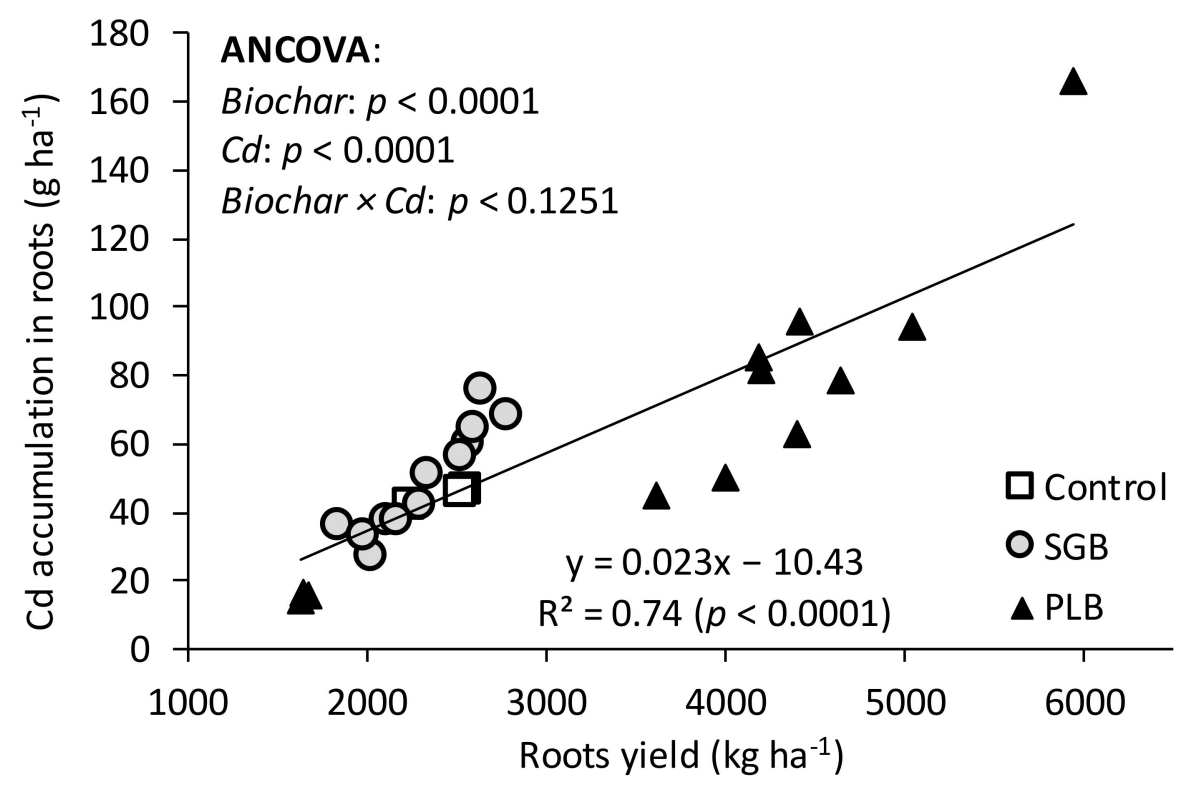

Figure 2. Relationship between root yields and cadmium (Cd) accumulation in ryegrass roots as a function of biochar application rates. ANCOVA: analysis of covariance. When the interaction biochar $\times C d$ is $p \geq 0.05$, results of both biochars must be combined in a single linear regression.

\subsection{Cadmium Bioavailability}

Overall, DTPA-extractable Cd concentrations were higher for the control and decreased as the rates of biochars increased [11]. Previous studies also suggested that biochars incorporation to soils effectively decreased the Cd availability as assessed by DTPA [33-38]. In this study, we correlated the DTPA-extractable $\mathrm{Cd}$ from the biochar-treated soils with $\mathrm{Cd}$ and accumulation in ryegrass plant parts (Table 4). Some studies revealed that the dilution effect caused by the increase of plant biomass also contributed to the decrease of Cd concentrations in plants cultivated in biochar-treated soils [33-35], which suggests that such decrease is not a consequence of biochar application. However, the positive correlations (and no correlations) found for DTPA-extractable $\mathrm{Cd}$ in the soil and Cd accumulation in ryegrass plant parts, when the biomass is accounted for, for both biochars, ensure the data reliability obtained in this study (Table 4). The absence of correlation suggests that DTPA-extractable Cd is better correlated with its uptake in plant parts, as shown in the previous study [11].

Table 4. Pearson correlations between DTPA-extractable Cd contents in the soil ( $x$-axis) and Cd accumulation in ryegrass shoots and roots.

\begin{tabular}{cccc}
\hline Treatment & Shoots & Roots & Shoots + Roots \\
\hline & & Cd accumulation $(y$-axis $)$ & $0.33^{* *}$ \\
SGB & $0.60^{*}$ & $0.50^{\mathrm{NS}}$ & $0.47^{\mathrm{NS}}$ \\
PLB & $0.69^{* *}$ & $0.36^{\mathrm{NS}}$ & $0.31^{\mathrm{NS}}$
\end{tabular}

${ }^{*}: p<0.05 .{ }^{* *}: p<0.01 .{ }^{\mathrm{NS}}:$ non-significant $(p>0.05)$. SGB: switchgrass-derived biochar. PLB: poultry litter-derived biochar. SGB + PLB: the two biochar-treated soils.

\subsection{Cadmium Transfer Factor}

Table 5 shows the $\mathrm{Cd}$ transfer factor (TF) from ryegrass roots to shoots. The TF of accumulated Cd was similar to that observed by Antonangelo and Zhang [11] when evaluating the simple $\mathrm{Cd}$ uptake TF. Therefore, the TF decreased as the application of both biochars increased (Table 5). A lower TF indicates higher $\mathrm{Cd}$ accumulation in roots and lower transference to aboveground plant parts, which lowers the risk to the primary consumer $[33,39]$. Other studies have also reported the preferential accumulation of $\mathrm{Cd}$ in 
the roots of grasses rather than in shoots, such as ryegrass [31] and rice [32]. In our study, it is evident that the accumulated $\mathrm{Cd}$ was higher in the roots of ryegrass than in the shoots even for the control. On average, TF as a function of PLB application was higher than that of SGB, which is consistent with the fact that ryegrass shoots yielded better under the PLB amendment; which was also closely related to the $\mathrm{N}$ removal, thus resulted in higher $\mathrm{Cd}$ removal aboveground when compared to SGB. The maximum Cd TF was reached when $206 \pm 38 \mathrm{~kg} \mathrm{~N} \mathrm{ha}^{-1}$ was removed in ryegrass shoots (Figure 3). This is close to a TF of 0.5 obtained between the control and the lowest rate of PLB application rate $(0.5 \%)$.

Table 5. The transfer factor (TF) of accumulated $\mathrm{Cd}$ from ryegrass roots to shoots as a function of biochar (B) application rates (R).

\begin{tabular}{|c|c|c|c|c|c|c|}
\hline \multirow{3}{*}{$\begin{array}{c}\text { Rate (\%) } \\
0\end{array}$} & \multicolumn{6}{|c|}{ Transfer Factor (TF) } \\
\hline & \multicolumn{2}{|c|}{ SGB } & \multicolumn{2}{|c|}{ PLB } & \multicolumn{2}{|c|}{ Mean } \\
\hline & 0.66 & $\mathrm{aA}$ & 0.66 & $\mathrm{aA}$ & 0.66 & a \\
\hline 0.5 & 0.25 & $\mathrm{bB}$ & 0.4 & $\mathrm{bA}$ & 0.32 & $\mathrm{~b}$ \\
\hline 1 & 0.25 & $\mathrm{bcB}$ & 0.35 & $\mathrm{bA}$ & 0.3 & $\mathrm{~b}$ \\
\hline 2 & 0.28 & $\mathrm{bB}$ & 0.41 & $\mathrm{bA}$ & 0.35 & $\mathrm{~b}$ \\
\hline 4 & 0.06 & $\mathrm{cA}$ & 0.15 & $\mathrm{cA}$ & 0.11 & c \\
\hline Mean & 0.3 & B & 0.39 & $\mathrm{~A}$ & & \\
\hline$R$ & \multicolumn{6}{|c|}{$p<0.05$} \\
\hline$B$ & \multicolumn{6}{|c|}{$p<0.05$} \\
\hline$R \times B$ & \multicolumn{6}{|c|}{$p=0.21$} \\
\hline
\end{tabular}

Different lowercase letters in columns (within biochar rates) and uppercase letters in rows (same biochar rate) are significantly different at $p<0.05$ (Tukey). SGB: switchgrass-derived biochar. PLB: poultry litter-derived biochar. $T F=C d$ removal in shoots $\div$ Cd accumulated in roots.

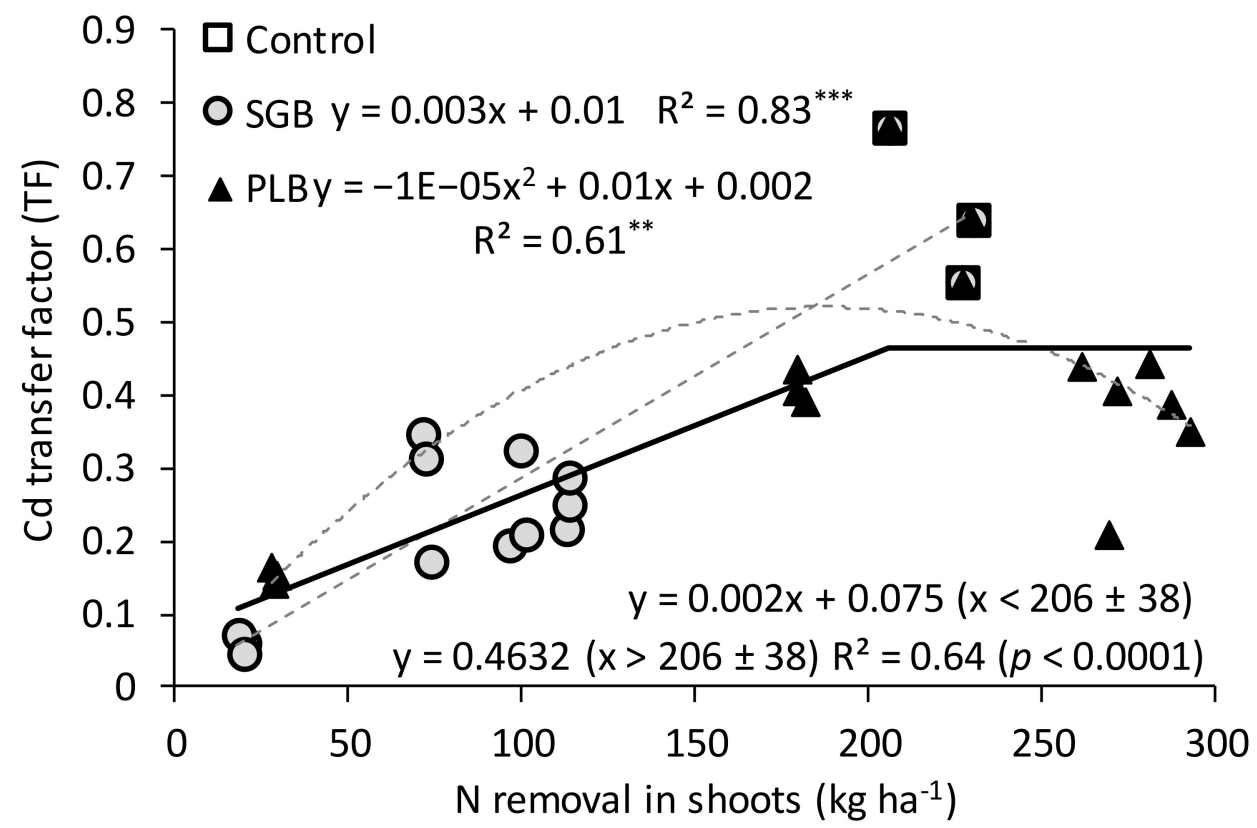

Figure 3. Linear and quadratic regression models (gray dashed lines) for Cd transfer factor and $\mathrm{N}$ removal in ryegrass shoots as a function of applications of switchgrass (SGB) and poultry litter-derived biochars (PLB). The black solid line represents a linear regression with a plateau model combining both biochar-treated soils (SGB + PLB). The black dashed vertical line indicates the joint point (plateau point) of $\mathrm{N}$ removal where the $\mathrm{Cd}$ transfer factor ceases to increase. ${ }^{* *}: p<0.01 .{ }^{* * *}: p<0.001$.

The linear with plateau model was converged from the whole dataset of measurements and for both biochars combined, which is probably a result of the simple linear regression obtained for SGB and a quadratic regression for PLB (Figure 3). The highest point of which 
the linear line reaches its maximum in the SGB is close to the maximum point reached with the quadratic line drawn in the PLB before the $\mathrm{Cd}$ TF values begin to reduce. Therefore, a maximum point (plateau or joint point), was obtained for both biochars combined thus indicating an optimum $\mathrm{N}$ removal in ryegrass shoots in which $\mathrm{Cd}$ removal also reached its limit (Figure 3).

\section{Discussion}

Our research demonstrated that $\mathrm{Cd}$ accumulation in ryegrass plant parts is proportionally affected by $\mathrm{N}$ uptake and ryegrass yields. Nitrogen fertilization may indeed change the phytoavailability of $\mathrm{Cd}$ in the growth medium and its absorption by plants [40]. Additionally, several studies have shown that $\mathrm{N}$ fertilization increases $\mathrm{Cd}$ concentration in plant tissues $[16,41,42]$. One of the reasons may rely on a possible synergic effect between nitrate $\left(\mathrm{NO}_{3}{ }^{-}\right)$and $\mathrm{Cd}[42-45]$ while the ratio between $\mathrm{NO}_{3}{ }^{-}$and ammonium- $\mathrm{NH}_{4}{ }^{+}$might influence the accumulation of $\mathrm{Cd}$ in plants as well [46]. Commonly, $\mathrm{NH}_{4}{ }^{+}$easily undergoes the nitrification process in aerobic environments and forms $\mathrm{NO}_{3}{ }^{-}$, which is taken up by plants, and such a process releases $\mathrm{H}^{+}$in the soil solution thus reducing its $\mathrm{pH}$ and increasing the $\mathrm{Cd}$ bioavailability. In this sense, more research is encouraged to test nitrate and ammoniacal sources of nitrogen fertilizers to evaluate their impact on toxic elements removal. Additionally, evaluating if biochars produced from different feedstocks are a better source of $\mathrm{NO}_{3}{ }^{-}$or $\mathrm{NH}_{4}{ }^{+}$would contribute to the better understanding of metal remediation practices if biochars can immobilize the metal and the same time increase the toxic element removal by providing $\mathrm{N}$ efficiently while keeping metal concentration below the threshold for animal grazing.

A higher accumulation of $\mathrm{Cd}$ was found in the ryegrass roots as compared with the shoots. Since the root is the first plant part in contact with $\mathrm{Cd}$ in contaminated soil and its structural component likely accumulates the largest amount of $\mathrm{Cd}$ present in the plant tissues $[47,48]$. This is a physiological strategy in which plants phytostabilize the metal in the roots to prevent toxic elements from reaching the xylem, being transported to the shoots, and damaging the photosynthetic apparatus of plants [46] This prevention of $\mathrm{Cd}$ transport to the shoots may occur through the synthesis of chelants or even physical barriers that prevent the $\mathrm{Cd}$ movement in the apoplast [49]. Therefore, more attention must be paid to plants metabolism and molecular mechanisms to reveal the direct role of organic amendments, such as biochar, in future phytoremediation studies, as pointed out by Liu et al. [50]. For example, the recent study of Peco et al. [51] has found Biscutella auriculata L., a wild herbaceous species that grows on pastureland, as a new Cd-tolerant plant capable of activating efficient metal-sequestering mechanisms in the root surfaces and leaves, and of inducing phytochelatins in both parts, besides stimulating antioxidative defenses in roots.

\section{Conclusions}

Cadmium removal was the highest at the 1\% PLB rate accompanied by the highest ryegrass yield. However, the $\mathrm{Cd}$ concentration in grazable forage remained acceptable. The $\mathrm{Cd}$ transfer factor from ryegrass roots to shoots increased when up to $206 \pm 38 \mathrm{~kg} \mathrm{~N}^{-1}$ was removed in ryegrass shoots. Application of up to 1\% PLB is a viable option, since it is a practical rate for handling operations requiring less volume of material than SGB.

Author Contributions: Conceptualization, J.A.; methodology, J.A. and H.Z.; validation, J.A. and H.Z.; formal analysis, J.A.; investigation, J.A. and H.Z.; resources, H.Z.; data curation, J.A.; writingoriginal draft preparation, J.A.; writing — review and editing, J.A. and H.Z.; visualization, J.A.; supervision, H.Z.; project administration, H.Z.; funding acquisition, H.Z. All authors have read and agreed to the published version of the manuscript.

Funding: This work was supported by the Oklahoma Agricultural Experiment Station.

Institutional Review Board Statement: Not applicable.

Informed Consent Statement: Not applicable. 
Data Availability Statement: Raw data were generated at an environmentally controlled growth chamber located at CERL (Controlled Environmental Research Lab) Central, Oklahoma State University, main campus. Derived data supporting the findings of this study are available from the corresponding author J.A. on request.

Conflicts of Interest: The authors declare no conflict of interest.

\section{References}

1. Zeng, X.; Xu, H.; Lu, J.; Chen, Q.; Li, W.; Wu, L.; Tang, J.; Ma, L. The Immobilization of Soil Cadmium by the Combined Amendment of Bacteria and Hydroxyapatite. Sci. Rep. 2020, 10, 1-8. [CrossRef] [PubMed]

2. Jacquiod, S.; Cyriaque, V.; Riber, L.; Al-Soud, W.A.; Gillan, D.C.; Wattiez, R.; Sørensen, S.J. Long-term industrial metal contamination unexpectedly shaped diversity and activity response of sediment microbiome. J. Hazard. Mater. 2018, 344, $299-307$. [CrossRef]

3. Martínez-Sánchez, M.J.; Martínez-López, S.; Martínez-Martínez, L.B.; Pérez-Sirvent, C. Importance of the oral arsenic bioaccessibility factor for characterising the risk associated with soil ingestion in a mining-influenced zone. J. Environ. Manag. 2013, $116,10-17$. [CrossRef]

4. Sinha, S.; Mishra, R.K.; Sinam, G.; Mallick, S.; Gupta, A.K. Comparative Evaluation of Metal Phytoremediation Potential of Trees, Grasses, and Flowering Plants from Tannery-Wastewater-Contaminated Soil in Relation with Physicochemical Properties. Soil Sediment Contam. Int. J. 2013, 22, 958-983. [CrossRef]

5. He, M.; Shi, H.; Zhao, X.; Yu, Y.; Qu, B. Immobilization of Pb and Cd in Contaminated Soil Using Nano-Crystallite Hydroxyapatite. Procedia Environ. Sci. 2013, 18, 657-665. [CrossRef]

6. Niu, L.; Yang, F.; Xu, C.; Yang, H.; Liu, W. Status of metal accumulation in farmland soils across China: From distribution to risk assessment. Environ. Pollut. 2013, 176, 55-62. [CrossRef]

7. Neuberger, J.S.; Hu, S.C.; Drake, K.D.; Jim, R. Potential health impacts of heavy-metal exposure at the Tar Creek Superfund site, Ottawa County, Oklahoma. Environ. Geochem. Health 2008, 31, 47-59. [CrossRef] [PubMed]

8. Brown, S.; Compton, H.; Basta, N. Field Test of In Situ Soil Amendments at the Tar Creek National Priorities List Superfund Site. J. Environ. Qual. 2007, 36, 1627-1634. [CrossRef] [PubMed]

9. Beattie, R.E.; Henke, W.; Davis, C.; Mottaleb, M.A.; Campbell, J.H.; Mcaliley, L.R. Quantitative analysis of the extent of heavymetal contamination in soils near Picher, Oklahoma, within the Tar Creek Superfund Site. Chemosphere 2017, 172, 89-95. [CrossRef] [PubMed]

10. Gouzie, D. Potential Remediation Methods and Their Applicability to the Tri-State Mining District, USA. In Proceedings of the GSA Annual Meeting, Indianapolis, IN, USA, 4-7 November 2018.

11. Antonangelo, J.A.; Zhang, H. Heavy metal phytoavailability in a contaminated soil of northeastern Oklahoma as affected by biochar amendment. Environ. Sci. Pollut. Res. 2019, 26, 33582-33593. [CrossRef] [PubMed]

12. Ji, S.; Gao, L.; Chen, W.; Su, J.; Shen, Y. Urea application enhances cadmium uptake and accumulation in Italian ryegrass. Environ. Sci. Pollut. Res. 2020, 27, 34421-34433. [CrossRef] [PubMed]

13. Singh, J.P.; Singh, B.; Karwasra, S.P.S. Yield and uptake response of lettuce to cadmium as influenced by nitrogen application. Fertil. Res. 1988, 18, 49-56. [CrossRef]

14. Zhang, R.-R.; Liu, Y.; Xue, W.-L.; Chen, R.-X.; Du, S.-T.; Jin, C.-W. Slow-release nitrogen fertilizers can improve yield and reduce Cd concentration in pakchoi (Brassica chinensis L.) grown in Cd-contaminated soil. Environ. Sci. Pollut. Res. 2016, 23, 25074-25083. [CrossRef]

15. Wei, S.; Ji, D.; Twardowska, I.; Li, Y.; Zhu, J. Effect of different nitrogenous nutrients on the cadmium hyperaccumulation efficiency of Rorippa globosa (Turcz.) Thell. Environ. Sci. Pollut. Res. 2015, 22, 1999-2007. [CrossRef] [PubMed]

16. Liu, W.; Zhang, C.; Hu, P.; Luo, Y.; Wu, L.; Sale, P.; Tang, C. Influence of nitrogen form on the phytoextraction of cadmium by a newly discovered hyperaccumulator Carpobrotus rossii. Environ. Sci. Pollut. Res. 2016, 23, 1246-1253. [CrossRef]

17. Chen, Y.; Liu, M.; Deng, Y.; Zhong, F.; Xu, B.; Hu, L.; Wang, M.; Wang, G. Comparison of ammonium fertilizers, EDTA, and NTA on enhancing the uptake of cadmium by an energy plant, Napier grass (Pennisetum purpureum Schumach). J. Soils Sediments 2017, 17, 2786-2796. [CrossRef]

18. Symanowicz, B.; Kalesa, S.; Jaremko, D.; Niedbała, M. Effect of nitrogen application and year on concentration of Cu, Zn, Ni, Cr, $\mathrm{Pb}$ and $\mathrm{Cd}$ in herbage of Galega orientalis Lam. Plant Soil Environ. 2016, 61, 11-16. [CrossRef]

19. Benyas, E.; Owens, J.; Seyedalikhani, S.; Robinson, B. Cadmium Uptake by Ryegrass and Ryegrass-Clover Mixtures under Different Liming Rates. J. Environ. Qual. 2018, 47, 1249-1257. [CrossRef] [PubMed]

20. Liu, L.; Zhang, Q.; Hu, L.; Tang, J.; Xu, L.; Yang, X.; Yong, J.W.H.; Chen, X. Legumes Can Increase Cadmium Contamination in Neighboring Crops. PLoS ONE 2012, 7, e42944. [CrossRef]

21. Malcolm, B.J.; Moir, J.L.; Cameron, K.C.; Di, H.J.; Edwards, G.R. Influence of plant growth and root architecture of Italian ryegrass (Lolium multiflorum) and tall fescue (Festuca arundinacea) on N recovery during winter. Grass Forage Sci. 2015, 70, 600-610. [CrossRef]

22. Mongkhonsin, B.; Nakbanpote, W.; Meesungnoen, O.; Prasad, M.N.V. Adaptive and Tolerance Mechanisms in Herbaceous Plants Exposed to Cadmium. Cadmium Toxic. Toler. Plants 2019, 73-109.

23. Han, S.; Li, X.; Amombo, E.; Fu, J.; Xie, Y. Cadmium Tolerance of Perennial Ryegrass Induced by Aspergillus aculeatus. Front. Microbiol. 2018, 9, 1579. [CrossRef] [PubMed] 
24. Antonangelo, J.A.; Zhang, H.; Sun, X.; Kumar, A. Physicochemical properties and morphology of biochars as affected by feedstock sources and pyrolysis temperatures. Biochar 2019, 1, 325-336. [CrossRef]

25. Church, C.; Spargo, J.; Fishel, S. Strong Acid Extraction Methods for “Total Phosphorus" in Soils: EPA Method 3050B and EPA Method 3051. Agric. Environ. Lett. 2017, 2, 160037. [CrossRef]

26. Richards, J.R.; Schroder, J.L.; Zhang, H.; Basta, N.T.; Wang, Y.; Payton, M.E. Trace Elements in Benchmark Soils of Oklahoma. Soil Sci. Soc. Am. J. 2012, 76, 2031-2040. [CrossRef]

27. Wu, J.; Song, Q.; Zhou, J.; Wu, Y.; Liu, X.; Liu, J.; Zhou, L.; Wu, Z.; Wu, W. Cadmium threshold for acidic and multi-metal contaminated soil according to Oryza sativa L. Cadmium accumulation: Influential factors and prediction model. Ecotoxicol. Environ. Saf. 2021, 208, 111420. [CrossRef]

28. Jones, J.B.; Case, V.W. Sampling, Handling, and Analyzing Plant Tissue Samples. SSSA Book Ser. Soil Test. Plant Anal. $2018,3,389-427$.

29. Rigby, H.; Smith, S.R. The significance of cadmium entering the human food chain via livestock ingestion from the agricultural use of biosolids, with special reference to the UK. Environ. Int. 2020, 143, 105844. [CrossRef]

30. Feng, D.; Huang, C.; Xu, W.; Qin, Y.; Li, Y.; Li, T.; Yang, M.; He, Z. Difference of Cadmium Bioaccumulation and Transportation in Two Ryegrass Varieties and the Correlation between Plant Cadmium Concentration and Soil Cadmium Chemical Forms. Wirel. Pers. Commun. 2020, 110, 291-307. [CrossRef]

31. Jarvis, S.C.; Jones, L.H.P.; Hopper, M.J. Cadmium uptake from solution by plants and its transport from roots to shoots. Plant Soil 1976, 44, 179-191. [CrossRef]

32. Huang, L.; Li, W.C.; Tam, N.F.Y.; Ye, Z. Effects of root morphology and anatomy on cadmium uptake and translocation in rice (Oryza sativa L.). J. Environ. Sci. 2019, 75, 296-306. [CrossRef]

33. Zhang, G.; Guo, X.; Zhao, Z.; He, Q.; Wang, S.; Zhu, Y.; Yan, Y.; Liu, X.; Sun, K.; Zhao, Y.; et al. Effects of biochars on the availability of heavy metals to ryegrass in an alkaline contaminated soil. Environ. Pollut. 2016, 218, 513-522. [CrossRef]

34. Lu, K.; Yang, X.; Shen, J.; Robinson, B.; Huang, H.; Liu, D.; Bolan, N.; Pei, J.; Wang, H. Effect of bamboo and rice straw biochars on the bioavailability of $\mathrm{Cd}, \mathrm{Cu}, \mathrm{Pb}$ and $\mathrm{Zn}$ to Sedum plumbizincicola. Agric. Ecosyst. Environ. 2014, 191, 124-132. [CrossRef]

35. Park, J.H.; Choppala, G.K.; Bolan, N.S.; Chung, J.W.; Chuasavathi, T. Biochar reduces the bioavailability and phytotoxicity of heavy metals. Plant Soil 2011, 348, 439-451. [CrossRef]

36. Al-Wabel, M.I.; Usman, A.R.; El-Naggar, A.H.; Aly, A.A.; Ibrahim, H.M.; Elmaghraby, S.; Al-Omran, A. Conocarpus biochar as a soil amendment for reducing heavy metal availability and uptake by maize plants. Saudi J. Biol. Sci. 2015, 22, 503-511. [CrossRef]

37. Li, H.; Ye, X.; Geng, Z.; Zhou, H.; Guo, X.; Zhang, Y.; Zhao, H.; Wang, G. The influence of biochar type on long-term stabilization for $\mathrm{Cd}$ and $\mathrm{Cu}$ in contaminated paddy soils. J. Hazard. Mater. 2016, 304, 40-48. [CrossRef]

38. Mohamed, I.; Zhang, G.-S.; Li, Z.-G.; Liu, Y.; Chen, F.; Dai, K. Ecological restoration of an acidic Cd contaminated soil using bamboo biochar application. Ecol. Eng. 2015, 84, 67-76. [CrossRef]

39. Karami, N.; Clemente, R.; Moreno-Jiménez, E.; Lepp, N.W.; Beesley, L. Efficiency of green waste compost and biochar soil amendments for reducing lead and copper mobility and uptake to ryegrass. J. Hazard. Mater. 2011, 191, 41-48. [CrossRef] [PubMed]

40. Valdez-González, J.C.; López-Chuken, U.J.; Guzmán-Mar, J.L.; Flores-Banda, F.; Hernández-Ramírez, A.; Hinojosa-Reyes, L. Saline irrigation and $\mathrm{Zn}$ amendment effect on Cd phytoavailability to Swiss chard (Beta vulgaris L.) grown on a long-term amended agricultural soil: A human risk assessment. Environ. Sci. Pollut. Res. 2014, 21, 5909-5916. [CrossRef]

41. Bauddh, K.; Singh, R.P. Effects of organic and inorganic amendments on bio-accumulation and partitioning of Cd in Brassica juncea and Ricinus communis. Ecol. Eng. 2015, 74, 93-100. [CrossRef]

42. Yang, Y.; Xiong, J.; Chen, R.; Fu, G.; Chen, T.; Tao, L. Excessive nitrate enhances cadmium (Cd) uptake by up-regulating the expression of OsIRT1 in rice (Oryza sativa). Environ. Exp. Bot. 2016, 122, 141-149. [CrossRef]

43. Jalloh, M.A.; Chen, J.; Zhen, F.; Zhang, G. Effect of different $\mathrm{N}$ fertilizer forms on antioxidant capacity and grain yield of rice growing under Cd stress. J. Hazard. Mater. 2009, 162, 1081-1085. [CrossRef]

44. Luo, B.F.; Du, S.T.; Lu, K.X.; Liu, W.J.; Lin, X.Y.; Jin, C.W. Iron uptake system mediates nitrate-facilitated cadmium accumulation in tomato (Solanum lycopersicum) plants. J. Exp. Bot. 2012, 63, 3127-3136. [CrossRef]

45. Hu, J.; Wu, S.; Wu, F.; Leung, H.M.; Lin, X.; Wong, M.H. Arbuscular mycorrhizal fungi enhance both absorption and stabilization of Cd by Alfred stonecrop (Sedum alfredii Hance) and perennial ryegrass (Lolium perenne L.) in a Cd-contaminated acidic soil. Chemosphere 2013, 93, 1359-1365. [CrossRef]

46. Nogueirol, R.C.; Monteiro, F.A.; Junior, J.C.D.S.; Azevedo, R.A. NO3-/NH4+ proportions affect cadmium bioaccumulation and tolerance of tomato. Environ. Sci. Pollut. Res. 2018, 25, 13916-13928. [CrossRef] [PubMed]

47. Gallego, S.M.; Pena, L.B.; Barcia, R.A.; Azpilicueta, C.E.; Iannone, M.F.; Rosales, E.P.; Zawoznik, M.S.; Groppa, M.D.; Benavides, M.P. Unravelling cadmium toxicity and tolerance in plants: Insight into regulatory mechanisms. Environ. Exp. Bot. 2012, 83, 33-46. [CrossRef]

48. Alves, L.R.; Monteiro, C.C.; Carvalho, R.F.; Ribeiro, P.C.; Tezotto, T.; Azevedo, R.A.; Gratão, P.L. Cadmium stress related to root-to-shoot communication depends on ethylene and auxin in tomato plants. Environ. Exp. Bot. 2017, 134, 102-115. [CrossRef]

49. Lux, A.; Martinka, M.; Vaculik, M.; White, P.J. Root responses to cadmium in the rhizosphere: A review. J. Exp. Bot. 2010, 62, 21-37. [CrossRef]

50. Liu, M.; Zhao, Z.; Wang, L.; Xiao, Y. Influences of rice straw biochar and organic manure on forage soybean nutrient and Cd uptake. Int. J. Phytoremediat. 2020, 23, 53-63. [CrossRef]

51. Peco, J.D.; Campos, J.A.; Romero-Puertas, M.C.; Olmedilla, A.; Higueras, P.; Sandalio, M.L. Characterization of mechanisms involved in tolerance and accumulation of Cd in Biscutella auriculata L. Ecotoxicol. Environ. Saf. 2020, 201, 110784. [CrossRef] 